\title{
ERP Systems in Croatian Enterprises
}

\author{
Krunoslav HORNUNG, Maja HORNUNG
}

\begin{abstract}
Successful implementation of the ERP system enables the management to integrate all business processes and functions, thus increasing the company's competitive advantage in today's turbulent market. Considering potential benefits of ERP system implementation, companies decide to invest significant financial resources and time to implement ERP system. However, there are still a number of projects of ERP system implementation that failed due to various critical success factors, which are quoted in the literature. Since the application of ERP systems is one of the key indicators highlighted by the European Commission under the Digital Agenda for Europe (EU 2020), which sets the European Union's (EU) growth targets by 2020, it is important to make the analysis of the status of the ERP system use in the Republic of Croatia. Given that critical factors of the successful ERP implementation are investigated to a lesser extent in the Republic of Croatia, the aim of this paper is to find out which companies in the Republic of Croatia consider the most important critical success factors, taking into account the specificities of business in relation to the developed countries, and possible differences in attitudes among large companies and medium and small businesses. For this purpose, an online questionnaire survey was carried out and a comparative analysis among large companies and medium and small enterprises was conducted using the Mann-Whitney $\mathrm{U}$ test.
\end{abstract}

Keywords: comparative analysis; critical success factors; ERP implementation; Mann-Whitney U test; questionnaire survey

\section{INTRODUCTION}

Development of techniques and technology, globalisation, and the increasingly complex business environment require the flow and processing of a huge amount of information (procurement of product parts and materials, spare parts, maintenance, inventory management, finance, human resources, ...) necessary for proper and timely decision making. Enterprise Resource Planning (ERP) is the concept of enterprise management with the aim of integrating business processes and strategic planning of all resources by utilizing information and communication capabilities of new computer systems [1].

The ICT development is decisive for the realisation of the ERP concept. Current ERP systems are information systems that have met this challenge, but two "problems" still need to be solved. The first refers to the selection and compilation of the information technology infrastructure with the necessary software for saving, analysing and distributing information that needs to be accurate and updated. On the other hand, it is necessary to use the information obtained in the planning and decision-making process efficiently and in a timely manner as is achieved through meaningful flow of information. The ES (enterprise system) enables the enterprise to integrate all the data used in the organization [2]. The ERP system is fully integrated software that automates business processes and provides real-time access to information [3].

Implementing an ERP system is a long-term process that implies investing large amounts of financial resources, but it enables enterprises to perform better, efficiently and economically. Quality and efficiency are primarily manifested through better market positioning, and therefore obtaining greater confidence of business entities [4].

The papers on unsuccessful ERP implementation projects can be found in the literature, in which unsuccessful projects mean complete cancelling of ERP implementation project, as well as projects with deadline overrun and exceeding planned expenses [8-11]. According to the above criteria, the share of unsuccessful projects is very high, as stated in the Panorama Consulting Solutions report, 2017 (Panorama Consulting Solutions.
2017 Report on ERP Systems \& Enterprise Software, 2017): in the last five years, approximately $59 \%$ of companies have exceeded the planned budget, and $65 \%$ have had a longer lifetime of ERP implementation project than planned.

Despite this, ERP implementation in the world is still increasing $[5,6,7,12,13,14,15,16]$.There are numerous papers published in this area, in which a lot of researchers have focused on the critical factors of ERP implementation $[3,17,18,19,20,21,22]$.

However, very few of them systematically handle the critical success factors (CSFs) that affect the success of ERP implementation in companies in the Republic of Croatia [23, 24].

The main goal of this paper and the research undertaken is to determine the status of ERP system in Croatia and to investigate the opinion of ERP system users on ERP implementation success factors in the Croatian circumstances in order to help companies prevent errors while implementing ERP system. It would be particularly interesting to find out whether there are differences among the small and medium-sized enterprises and large companies as far as the critical success factors are concerned, because they do not have the appropriate resources, expertise and experience to implement ERP system [25].

The article structure is as follows: the review of the literature on ERP implementation and critical success factors (CSF) is discussed in the second section. Section 3 presents the methodology of the research and the analysis of the results is presented in Section 4. The paper ends with the conclusion in Section 5.

\section{LITERATURE OVERVIEW}

There are numerous researches on the ERP systems that can be divided into three basic groups: ERP system implementation, ERP system benefits and research of cultural differences, as ERP implementation is spread across many countries and regions [26].

A brief overview of literature on ERP is given in the next subsection, followed by a brief overview of CSF literature on the ERP system implementation. 


\subsection{Implementation of the ERP System}

There are various definitions of the ERP systems. For some authors, ERP is a meaningful software solution that links all business processes with a unique IT architecture and software to access all relevant information concerning the companies [27]. Others look at ERP as a system for collecting and systematic updating of data and their processing [28]. The most important role of the ERP system as a computer-supported information system is the integration of the enterprise [29, 30].

In any case, ERP implementation means the implementation of the ERP concepts and introduction of the ERP software. Implementing the ERP system is a complex task that requires the involvement of all relevant stakeholders (e.g. management, information system specialists, employees, consultants and partners) [31].

The paper [32] provides an overview of the ERP systems and taxonomy of the ERP research that covers the main topics in this area. The case study on ERP implementation in the industry [33] is focused on the integration and development of the planning process in the ERP systems. The paper also addresses the approach to implementation and the benefits that companies derive from the ERP system implementation from the aspect of the enterprise size [34] as well as implementing the ERP systems to increase the competitive advantage in the market [31, 35], and the guidelines for aligning the ERP implementation with competitive strategy [36]. The ERP implementation is an extensive organisational change and not just a software installation [37]. Therefore the part of the paper is the comparison of the ERP system implementation in the countries in Asia, Europe and the USA with regard to diversity in national cultures and the need to adapt the generic systems to the specifics of a particular country [26].

\subsection{Critical Success Factors}

Despite all the benefits that an enterprise can achieve by implementing the ERP system, it has been shown that the implementation is not always successful [37]. For this reason, researches are focused on critical success factors and there is the extensive relevant literature dealing with this problem, but mainly with the focus on large enterprises and developed countries. Fewer researches deal with both developing countries and small and medium-sized enterprises. CSFs have an impact on the success of the ERP implementation and numerous authors have identified the factors considered critical to the success of the ERP implementation. CSF is studied by many authors, mostly before and during implementation, but rarely in the postimplementation phase [38].

One of the first surveys of critical success factors in implementing the ERP systems in small and medium-sized enterprises (SMEs) on Canadian companies' examples is described in the paper [39]. Their findings have confirmed the results of earlier researches that significant CSFs include management support, discipline process, qualified consultants, project management and user training. When comparing the ERP system implementation in the countries of Asia, Europe and the USA with regard to diversity in national cultures and the need to adapt the generic systems to the specifics of a particular country [26] the authors of the paper [40] found that these differences affect the success of ERP implementation.

Within the scope of their research, the authors of the paper [41] focus on human resources as one of the key success factors of the ERP implementation. The paper presents an overview of the critical success factors that affect the success of the ERP implementation, mentioned in the literature, and emphasize the organisational culture as a particularly important critical success factor. Consultant competences and absorption capacity are identified as critical success factors that affect knowledge transfer during the ERP implementation [42]. The paper [15] gives a comprehensive overview of previously identified CSFs in the implementation of the ERP systems according to the frequency of occurrence in the existing relevant literature.

The choice of a supplier of the ERP system is also a critical significant factor in the ERP implementation [43, 44]. Authors of the paper propose the framework for implementing the ERP system that takes into account the CSF priorities for SMEs.

As it can be seen in the literature review, most of the researches deal with an individual CSF, and a smaller number of published papers deal comprehensively with CSF $[15,16]$. The authors of the paper [15] have chosen the most important ones according to the frequency of CSF occurrences. They have selected $13 \mathrm{CSF}$ for the ERP implementation by reviewing 200 relevant articles. CSFs cannot be viewed independently because they interact with each other $[15,16]$.

As the ERP application is one of the many key indicators highlighted by the European Commission under the Digital Agenda for Europe-one of the seven pillars of the Europe 2020 strategy defining the targets for the growth of the European Union (EU) by 2020, it is important to analyse the state of application of the ERP systems in the Republic of Croatia.

\section{METHODOLOGY RESEARCH}

In the first phase of the research, a comprehensive overview of the relevant scientific literature on the ERP system implementation and CSF is made. The literature review includes scientific papers in journals that are presented in relevant databases (Web of Science (WoS), Science Direct, Emerald, Elsevier, ...).

In the second phase, a survey method is used to analyse the state of the ERP systems application in Croatia. A questionnaire that was sent via e-mail is used as an instrument of research. Based on the extensive review of the literature, the questionnaire contains 12 questions about the ERP system implementation, the current status of the company, basic organisation and respondent information, motivation for the ERP system introduction, system upgrading needs and improvements. The respondents did not have to answer the question about the company they come from which ensured their confidentiality. Closed questions with dichotomous responses are used in the questionnaire. Intensity responses (Likert's ordinal scale with five gradients used by respondents to rate the degree to which they agree or disagree with a statement (1-I disagree, ..., 2-I agree)), and multiple choice questions are 
offered in the questionnaire. In the next phase of the survey, a cover letter was sent via e-mail to a number of companies in the Republic of Croatia with a questionnaire request in order to gain an insight into problems related to the ERP system implementation in Croatian companies. The cover letter provides an URL with link to the online questionnaire so that the respondents submitted their answers online. The survey was conducted for over 2 months (January and February 2016). The companies were selected according to the company list published in Privredni vjesnik for 2014 (Privredni vjesnik, 400 Najvećih hrvatskih tvrtki u 2014./ 400 Largest Croatian Companies in 2014, August 2015 LXII, no. 3888). In choosing the companies, the intention was to cover the whole of Croatia, all sectors and sizes of companies. All counties in the Republic of Croatia were covered and a non-probabilistic (quota) sample was made. The invitation to fill in the online questionnaire was sent to the selected manufacturing and service companies from the mentioned list that had the highest total revenue in 2014. 300 Croatian companies were asked to complete the survey about ERP systems in Croatian companies, critical factors and their impact on the system implementation. A month later, a reminder to increase the response rate was sent. The total number of completed questionnaires is 74 , thus the overall response rate is $24.67 \%$, which is common for this type of survey of the ERP implementation [14, 19, 42]. Of the total number of completed questionnaires, $37 \%$ of respondents have not introduced and do not plan to introduce the ERP system or introducing the ERP system is in progress.

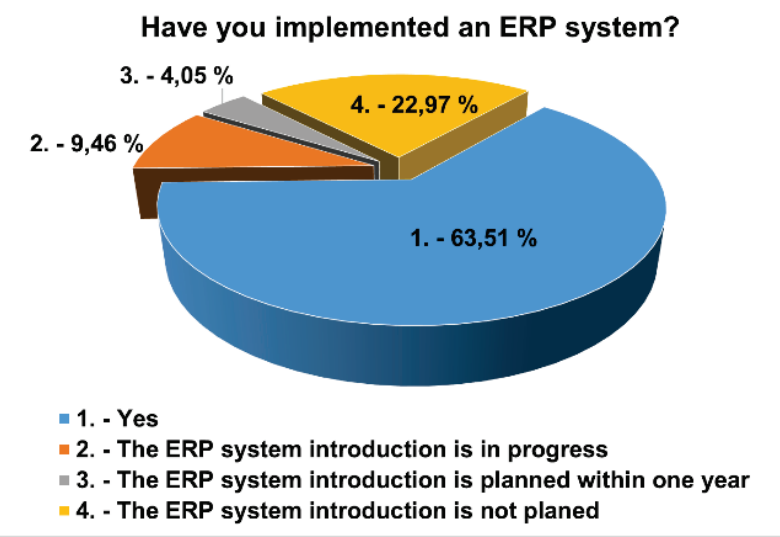

Figure 1 Status of the ERP system application in enterprises in the Republic of Croatia

The data collected by the survey were analysed by Tibco Statistica 13.3. using the methods of descriptive statistics. The Mann-Whitney U test was applied for the analysis of the questions, in which the 5-point Likert scale was used, since it is a non-probabilistic sample. First, the coding of variables was done, and then the attitudes of large (LE) and small and medium enterprises (SMEs) were compared.

\section{SURVEY RESULTS AND DISCUSSION}

In the first sub-section, general data on companies responding to the survey are processed, and in the second subsection critical success factors for the ERP system implementation in companies in Croatia are analysed.

\subsection{Analysis of the General Information from the Questionnaire}

Seventy-four companies, of which 38 large companies (250 and more employees) and 36 small and medium-sized companies responded to the questionnaire. Manufacturing and service industries are represented. According to the survey results, Fig. 1 shows the state of the ERP system implementation in Croatian companies, and Fig. 2 shows the share of companies participating in the survey according to the industry area.

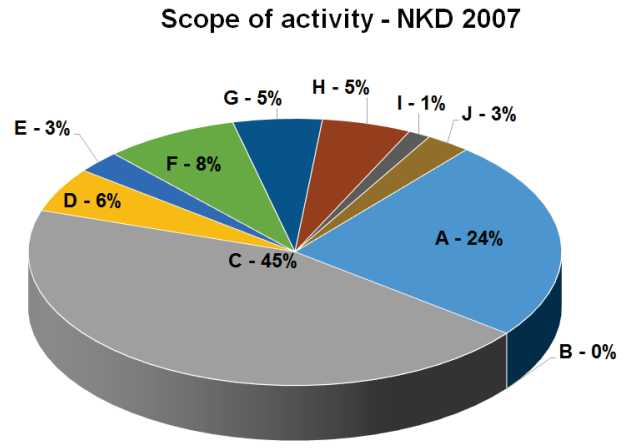
A - Agriculture, forestry and fishing
- B - Mining and quarrying
- C - Manufacturing
D - Electricity, gas, steam and air conditioning supply
- E - Water supply; sewerage, waste management and remediation activities
- F - Construction
- G - Wholesale and retail trade; repair of motor vehicles and motorcycles
- H - Transportation and storage
- I - Accommodation and food service activities
- J - Information and communication

Figure 2 The share of companies participating in the survey per scope of activity (according to NCEA - NKD 2007)

$63.51 \%$ of the companies introduced the ERP system, while up to $22.97 \%$ of companies are not planning to introduce ERP systems.

According to the results of the survey conducted in the Republic of Croatia, ERP systems of domestic and foreign suppliers are equally used. From foreign suppliers, the most frequently used system is SAP.

Several modules have been implemented to cover as many as possible departments in the company. The modules most often implemented are those that encompass common data, i.e. $96.08 \%$, and accounting modules in $96.08 \%$ of cases.

In most cases, it was necessary to customize the system, even in $70.59 \%$ of companies. Customizations were conducted for several reasons, such as improved reporting $(58.82 \%)$, for better display usefulness rate $(11.76 \%)$, for product integration with other systems (41.18\%), for functionality improvements (64.71\%), and system customization to the existing business processes in $80.39 \%$ of companies.

As shown, most of the changes occurred due to the adapting the ERP system to business processes, and this is one of the reasons why a number of companies do not plan 
to introduce the ERP systems because the market solutions do not meet their business needs.

In the case of enterprises with ERP system implemented, the process $(74.51 \%)$ lasted from 7 to 24 months in most cases ( 7 - 12 months $47.06 \%$ and 12 to 24 months $27.45 \%$ ). Since $80.39 \%$ of surveyed enterprises use the system for more than two years, their experience is relevant to the results of the survey conducted.

\subsection{Analysis of Critical Success Factors of the ERP System Implementation}

The aim of this survey is to investigate the attitudes of SMEs and large companies on the critical success factors in implementing ERP systems, how CSFs are ranked in terms of their importance, and whether there are significant differences in the attitudes of SMEs and large enterprises to CSF. The instrument consists of 26 items (CSF1 to CSF26) which the participants of the survey were asked to evaluate. The degree of agreement with the statement that a particular particle (listed critical success factor) is of great importance in the ERP system implementation using the 5-point Likert type scale. The participants expressed their opinion with a single partial choice with one of the following options: 1-I strongly disagree; 2-I disagree; 3-I neither agree nor disagree; 4-I agree; 5-I strongly agree.

\begin{tabular}{|c|c|c|}
\hline \multirow{2}{*}{ Variable } & \multicolumn{2}{|c|}{ Valid N: 51, Cronbach alpha: 0.920071} \\
\hline & Item-Total Correl. & Alpha if deleted \\
\hline CSF1 & 0.540572 & 0.917035 \\
\hline CSF2 & 0.487516 & 0.917976 \\
\hline CSF3 & 0.403914 & 0.919109 \\
\hline CSF4 & 0.571525 & 0.916449 \\
\hline CSF5 & 0.571010 & 0.916506 \\
\hline CSF6 & 0.640517 & 0.915144 \\
\hline CSF7 & 0.205424 & 0.922236 \\
\hline CSF8 & 0.276947 & 0.920417 \\
\hline CSF9 & 0.412690 & 0.918879 \\
\hline CSF10 & 0.709463 & 0.914004 \\
\hline CSF11 & 0.359789 & 0.920028 \\
\hline CSF12 & 0.373739 & 0.919442 \\
\hline CSF13 & 0.596032 & 0.916629 \\
\hline CSF14 & 0.506710 & 0.917532 \\
\hline CSF15 & 0.494102 & 0.917751 \\
\hline CSF16 & 0.702328 & 0.913840 \\
\hline CSF17 & 0.540357 & 0.917100 \\
\hline CSF18 & 0.543834 & 0.916923 \\
\hline CSF19 & 0.615973 & 0.915993 \\
\hline CSF20 & 0.535864 & 0.917069 \\
\hline CSF21 & 0.563039 & 0.916687 \\
\hline CSF22 & 0.729904 & 0.913757 \\
\hline CSF23 & 0.595439 & 0.916006 \\
\hline CSF24 & 0.745302 & 0.913496 \\
\hline CSF25 & 0.650181 & 0.914969 \\
\hline CSF26 & 0.415392 & 0.919378 \\
\hline
\end{tabular}

The CSF (5-point Likert scale) response analysis was performed using the Mann-Whitney U test.

First, the coding of the variables was performed, and then, for comparison of the attitudes of small and medium and large enterprises, the Mann-Whitney U Test comparing two independent samples (SME and LE) was applied significance of the level $p=0.01$. The research hypothesis is that there are no statistically significant differences in the attitudes of small and medium-sized enterprises and large companies about the critical success factors. For determining the internal scale validity,
Cronbach's reliability coefficient, Alpha-if-deleted indicator and item-to-total correlation were applied (Tab. $1)$.

The values of the Cronbach alpha coefficients indicate that the scale used has a satisfactory level of reliability. Namely, the internal consistency (Cronbach's alpha) is 0.92, and the value of Cronbach's reliability coefficient is greater than 0.70 which means high reliability [45] to see if there are statements that reduce the reliability of a given scale or do not show a strong correlation with the corresponding measurement scale. The value of the Cronbach alpha coefficient, and thus the reliability of the scale, would be slightly increased by the removal of CSF7 and CSF8 factors, but it is only a slight increase in the Cronbach alpha values so CSF7 and CSF8 are retained in further analysis.

Tab. 2 shows the results of Mann-Whitney U Test, which compares the attitudes on the critical success factors of small and medium-sized enterprises with large companies. The Mann-Whitney U Test analysis was made with the significance level $p=0.01$.

Larger number of respondents rated all the CSFs mentioned in the questionnaire as significant with a high level of agreement (5-I strongly agree and 4-I agree).

According to the data in Tab. 2, it can be concluded that there is no statistically significant difference in the attitudes of large enterprises and small and medium enterprises about critical success factors or in the implementation of the ERP system (hypothesis H0 is accepted, with significance level $p=0.01$ ) As shown in Fig. 3, large companies and small and medium enterprises have identical views on the critical success factors: userfriendly user interface and operations (ease of operation, ease of learning (guideline, online help)); data conversion; continuous support from system manufacturers (warranties, consultants' services, trainings, speed of problem solving); organisational culture; low level of general computer literacy; and weak institutional support for enterprise informatisation.

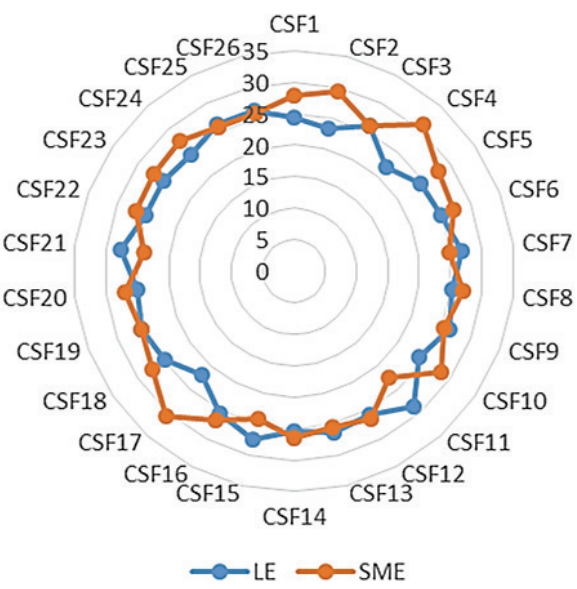

Figure 3 Polar graph for mean ranks of CSF (large companies and small and medium enterprises)

Most of the critical success factors are considered more significant by small and medium-sized enterprises than by large enterprises. Large enterprises, compared to small and medium-sized enterprises, rated higher only the following critical factors: business process reengineering, 
reputation of software manufacturer (finance, market share), top-management support and lack of methodologies for evaluation and selection of ERP system. But there is no statistically significant difference between the views of SMEs and large companies.

Table 2 The results of Mann-Whitney U Test, used to compare the attitudes on the critical success factors of small and medium-sized enterprises with large companies

\begin{tabular}{|c|c|c|c|c|c|c|c|c|}
\hline \multirow{2}{*}{ Critical success factors } & \multirow{2}{*}{ Variable } & \multicolumn{7}{|c|}{ Mann-Whitney U Test By variable Enterprise type Marked tests are significant at $p<, 01000$} \\
\hline & & Rank Sum LE & Rank Sum SME & $U$ & Z & $p$-value & $Z$-adjusted & $p$-value \\
\hline $\begin{array}{l}\text { Total expenses (price, maintenance costs, } \\
\text { consultants' costs) }\end{array}$ & CSF1 & 684,0000 & 642,0000 & 278,0000 & $-0,82345$ & 0,410255 & $-0,85311$ & 0,393601 \\
\hline Implementation period & CSF2 & 649,0000 & 677,0000 & 243,0000 & $-1,48599$ & 0,137283 & $-1,56003$ & 0,118754 \\
\hline $\begin{array}{l}\text { System functionality (module completeness, } \\
\text { proper function, security) }\end{array}$ & CSF3 & 726,5000 & 599,5000 & 320,5000 & $-0,01893$ & 0,984897 & $-0,02641$ & 0,978931 \\
\hline $\begin{array}{l}\text { User-friendly user interface and operations (ease } \\
\text { of operation, ease of learning) }\end{array}$ & CSF4 & 614,0000 & 712,0000 & 208,0000 & $-2,14853$ & 0,031672 & $-2,24044$ & 0,025063 \\
\hline $\begin{array}{l}\text { System flexibility (upgradeability, ease of } \\
\text { integration, easy upgrade) }\end{array}$ & CSF5 & 684,00 & 642,00 & 278,00 & $-0,82345$ & 0,410255 & $-0,89991$ & 0,368169 \\
\hline $\begin{array}{l}\text { Development of required software upgrades, } \\
\text { testing and troubleshooting }\end{array}$ & CSF6 & 701,00 & 625,00 & 295,00 & $-0,50164$ & 0,615921 & $-0,54341$ & 0,586847 \\
\hline Reengineering of business processes & CSF7 & 753,50 & 572,5000 & 296,5000 & 0,47324 & 0,636039 & 0,49428 & 0,621109 \\
\hline $\begin{array}{l}\text { High system reliability (stability, data backup, } \\
\text { data recovery) }\end{array}$ & CSF8 & 705,0000 & 621,0000 & 299,0000 & $-0,42592$ & 0,670166 & $-0,51379$ & 0,607397 \\
\hline Quality of information (reports) & CSF9 & 739,5000 & 586,5000 & 310,5000 & 0,20823 & 0,835051 & 0,26014 & 0,794758 \\
\hline Data conversion & CSF10 & 675,5000 & 650,5000 & 269,5000 & $-0,98435$ & 0,324944 & $-1,03255$ & 0,301817 \\
\hline $\begin{array}{l}\text { Software manufacturer's reputation (finance, } \\
\text { market share) }\end{array}$ & CSF11 & 804,5000 & 521,5000 & 245,5000 & 1,43866 & 0,150247 & 1,54121 & 0,123267 \\
\hline $\begin{array}{l}\text { The manufacturer provides good technical } \\
\text { capabilities (technical support, experience in } \\
\text { implementation) }\end{array}$ & CSF12 & 719,5000 & 606,5000 & 313,5000 & $-0,15144$ & 0,879630 & $-0,17435$ & 0,861594 \\
\hline $\begin{array}{l}\text { Continuous system manufacturer support } \\
\text { (warranties, consultants' Services, trainings, } \\
\text { troubleshooting rate) }\end{array}$ & CSF13 & 740,5000 & 585,5000 & 309,5000 & 0,22716 & 0,820301 & 0,27252 & 0,785222 \\
\hline Consultants' services & CSF14 & 714,5000 & 611,5000 & 308,5000 & $-0,24609$ & 0,805615 & $-0,25836$ & 0,796128 \\
\hline Top-management support & CSF15 & 770,5000 & 555,5000 & 279,5000 & 0,79505 & 0,426584 & 0,97207 & 0,331019 \\
\hline $\begin{array}{l}\text { Inadequate management's knowledge of on the } \\
\text { role and importance of ERP systems }\end{array}$ & CSF16 & 714,0000 & 612,0000 & 308,0000 & $-0,25555$ & 0,798297 & $-0,26455$ & 0,791355 \\
\hline $\begin{array}{l}\text { Lack of methodologies for evaluation and } \\
\text { selection of ERP systems }\end{array}$ & CSF17 & 618,5000 & 707,5000 & 212,5000 & $-2,06335$ & 0,039080 & $-2,12803$ & 0,033336 \\
\hline Project management & CSF18 & 695,5000 & 630,5000 & 289,5000 & $-0,60575$ & 0,544679 & $-0,64954$ & 0,515992 \\
\hline The project team's expertise & CSF19 & 728,0000 & 598,0000 & 322,0000 & 0,00946 & 0,992448 & 0,01056 & 0,991574 \\
\hline Organizational culture & CSF20 & 704,0000 & 622,0000 & 298,0000 & $-0,44485$ & 0,656428 & $-0,48242$ & 0,629509 \\
\hline Communication within the organization & CSF21 & 777,0000 & 549,0000 & 273,0000 & 0,91810 & 0,358570 & 1,03603 & 0,300190 \\
\hline Training and educating the user & CSF22 & 707,5000 & 618,5000 & 301,5000 & $-0,37860$ & 0,704988 & $-0,42723$ & 0,669213 \\
\hline $\begin{array}{l}\text { User involvement (level of initiative, knowledge, } \\
\text { and employee's desire to increase the level of } \\
\text { inf.) }\end{array}$ & CSF23 & 704,5000 & 621,5000 & 298,5000 & $-0,43539$ & 0,663283 & $-0,47141$ & 0,637345 \\
\hline User acceptance & CSF24 & 694,5000 & 631,5000 & 288,5000 & $-0,62468$ & 0,532179 & $-0,68330$ & 0,494418 \\
\hline Low level of the users' general computer literacy & CSF25 & 735,5000 & 590,5000 & 314,5000 & 0,13251 & 0,894582 & 0,13736 & 0,890742 \\
\hline $\begin{array}{l}\text { Lack of institutional support for enterprise } \\
\text { computerization }\end{array}$ & CSF26 & 735,0000 & 591,0000 & 315,0000 & 0,12304 & 0,902073 & 0,12671 & 0,899169 \\
\hline
\end{tabular}

Table 3 Mean ranks and assigned ranks according to mean ranks

\begin{tabular}{|c|c|c|c|c|c|}
\hline \multirow[b]{2}{*}{ Code } & \multirow{2}{*}{$\begin{array}{l}\text { Critical success factors } \\
\text { Critical success factors }\end{array}$} & \multicolumn{2}{|c|}{ Large companies } & \multicolumn{2}{|c|}{ SMEs } \\
\hline & & $\begin{array}{l}\text { Mean } \\
\text { ranks }\end{array}$ & $\begin{array}{l}\text { Assigned } \\
\text { ranks }\end{array}$ & $\begin{array}{l}\text { Mean } \\
\text { ranks }\end{array}$ & $\begin{array}{l}\text { Assigned } \\
\text { ranks }\end{array}$ \\
\hline CSF1 & Total expenses (price, maintenance costs, consultants' costs) & 24,43 & 21 & 27,91 & 5 \\
\hline CSF2 & Implementation period & 23,18 & 24 & 29,43 & 3 \\
\hline CSF3 & System functionality (module completeness, proper function, security) & 25,95 & 10 & 26,07 & 17 \\
\hline CSF4 & User-friendly user interface and operations (ease of operation, ease of learning) & 21,93 & 26 & 30,96 & 1 \\
\hline CSF5 & System flexibility (upgradeability, ease of integration, easy upgrade) & 24,43 & 22 & 27,91 & 6 \\
\hline CSF6 & Development of required software upgrades, testing and troubleshooting & 25,04 & 18 & 27,17 & 9 \\
\hline CSF7 & Reengineering of business processes & 26,91 & 4 & 24,89 & 23 \\
\hline CSF8 & High system reliability (stability, data backup, data recovery) & 25,18 & 15 & 27,00 & 12 \\
\hline CSF9 & Quality of information (reports) & 26,41 & 6 & 25,50 & 21 \\
\hline CSF10 & Data conversion & 24,13 & 23 & 28,28 & 4 \\
\hline CSF11 & Software manufacturer's reputation (finance, market share) & 28,73 & 1 & 22,67 & 26 \\
\hline CSF12 & The manufacturer provides good technical capabilities (technical support, experience in implementation) & 25,70 & 11 & 26,37 & 16 \\
\hline CSF13 & $\begin{array}{l}\text { Continuous system manufacturer support (warranties, consultants' Services, trainings, troubleshooting } \\
\text { rate) }\end{array}$ & 26,45 & 5 & 25,46 & 22 \\
\hline CSF14 & Consultants' services & 25,52 & 12 & 26,59 & 15 \\
\hline CSF15 & Top-management support & 27,52 & 3 & 24,15 & 24 \\
\hline CSF16 & Inadequate management's knowledge of on the role and importance of ERP systems & 25,50 & 13 & 26,61 & 14 \\
\hline CSF17 & Lack of methodologies for evaluation and selection of ERP systems & 22,09 & 25 & 30,76 & 2 \\
\hline CSF18 & Project management & 24,84 & 19 & 27,41 & 8 \\
\hline CSF19 & The project team's expertise & 26,00 & 9 & 26,00 & 18 \\
\hline CSF20 & Organizational culture & 25,14 & 17 & 27,04 & 10 \\
\hline CSF21 & Communication within the organization & 27,75 & 2 & 23,87 & 25 \\
\hline CSF22 & Training and educating the user & 25,27 & 14 & 26,89 & 13 \\
\hline CSF23 & User involvement (level of initiative, knowledge, and employee's desire to increase the level of inf.) & 25,16 & 16 & 27,02 & 11 \\
\hline CSF24 & User acceptance & 24,80 & 20 & 27,46 & 7 \\
\hline CSF25 & Low level of the users' general computer literacy & 26,27 & 7 & 25,67 & 20 \\
\hline CSF26 & Lack of institutional support for enterprise computerization & 26,25 & 8 & 25,70 & 19 \\
\hline
\end{tabular}


According to the analysis of the survey results of the attitudes of SMEs and the large companies on the critical success factors, the list of critical success factors for SMEs and large enterprises is presented in Tab. 2.

\section{CONCLUSION}

The ERP system implementation with the aim of increasing competitiveness is extremely important for the Croatian economy. Due to complexity of the implementation of the ERP system and the risk of the project implementation caused by various factors, it is important to understand the impact of the critical success factors that can lead to successful implementation of the ERP system. The results of the research have shown that, although there is no statistically significant difference in the companies' attitudes towards the critical success factors of the ERP implementation, small and mediumsized enterprises rank critical success factors differently compared to large companies. In small and medium-sized enterprises, the most important critical success factors are user-friendly interface and operation, lack of methodology for evaluation and selection of ERP systems, and the duration of implementation, which are, at the same time, the least significant critical success factors according to the large companies.

The drawback of the research is a non-probabilistic sample, but although the results of this research cannot be generalised because of it/this a non-probabilistic sample, it may still be useful to researchers and practitioners to gain insight into the issues of the ERP implementation in companies in Croatia.

In future studies, it would be useful to extend a set of critical success factors and involve more people from the same enterprises to participate in research.

\section{REFERENCES}

[1] Vuković, A., Džambas, I., \& Blažević, D. (2007). Razvoj ERP - koncepta i ERP-sustava (Development of ERP concept and ERP system). Eng. Rev., 27(2), 37-45.

[2] Davenport, T. H. (1998). Putting the enterprise into the enterprise system. Harvard Business Review, 76(4), 121131.

[3] Ağaoğlu, M., Yurtkoru, E. S., \& Ekmekçi, A. K. (2015). The effect of ERP implementation CSFs on business performance: an empirical study on users' perception. Procedia-Social and Behavioral Sciences, 210(2), 35-42. https://doi.org/10.1016/j.sbspro.2015.11.326

[4] Nah, F. F., Lau, J. L., \& Kuang, J. (2001, August). Critical factors for successful implementation of enterprise systems. Business Process Management Journal, 7, 285-296. https://doi.org/10.1108/14637150110392782

[5] Beheshti, H. M., Blaylock, B. K., Henderson, D. A., \& Lollar, J. G. (2014). Selection and critical success factors in successful ERP implementation. Competitiveness Review, 24(4), 357-375. https://doi.org/10.1108/CR-10-2013-0082

[6] Bansal, V. (2013, October). Identifying Critical Success Factors for ERP in SMEs through a Case Study. International Journal of Future Computer and Communication, 2(5). https://doi.org/10.1080/15416518.2013.831707

[7] Dadbin, S., Gholami, R., Standage, N., \& Hanafizadeh, P. (2010, April). The Core Critical Success Factors in Implementation of Enterprise Resource Planning Systems.
International Journal of Enterprise Information Systems, 6(2). https://doi.org/10.4018/jeis.2010040105

[8] Elragal, A. \& Haddara, M. (2013). The Impact of ERP Partnership Formation Regulations on the Failure of ERP Implementations. Procedia Technology, 9, 527-535. https://doi.org/10.1016/j.protcy.2013.12.059

[9] Rajan, C. A. \& Baral, R. (2015). Adoption of ERP system: An empirical study of factors influencing the usage of ERP and its impact on end user. IIMB Management Review, 27, 105-117. https://doi.org/10.1016/j.ïmb.2015.04.008

[10] Kumar, A. \& Gupta, P.C. (2012). Identification and Analysis of Failure Attributes for an ERP System. Procedia-Social and Behavioral Sciences, 65, 986-991. https://doi.org/10.1016/j.sbspro.2012.11.231

[11] Hustad, E., Haddara, M., \& Kalvenes, B. (2016). ERP and organizational misfits: An ERP customization journey. Procedia Computer Science, 100, 429-439. https://doi.org/10.1016/j.procs.2016.09.179

[12] Subhan, Z. \& Bhatti, A. T. (2015). Analysis of Enterprise Resource Planning Systems (ERPs) with Technical aspects, International Journal of Advent Research inComputer and Electronics (IJARCE), 2(6).

[13] Alaskari, O., Ahmad, M. M., \& Pinedo-Cuenca, R. (2014). Critical Success Factors (CSFs) for Lean Tools and ERP Systems implementation in manufacturing SMEs. Int. J. Lean Enterprise Research, 1(2). https://doi.org/10.1504/IJLER.2014.066834

[14] Somers, T. M. \& Nelson, K. G. (2004). A taxonomy of players and activities across ERP project life cycle. Information \& Management, 41, 257-278. https://doi.org/10.1016/S0378-7206(03)00023-5

[15] Hanafiadeh, P., Gholami, R., Dadbin, S., \& Standage, N. (2010). The core critical success factors in implementation of enterprise resource planning systems. International journal of enterprise information systems, 6(2), 82-111. https://doi.org/10.4018/jeis.2010040105

[16] Denolf, J. M., Trienekens, J. H., Wognum, P. M. (Nel), van der Vorst, J. G. A. J., \& Omta S.W.F. (Onno). (2015). Towards a framework of critical success factors for implementing supply chain information systems. Computers in Industry, 68, 16-26. https://doi.org/10.1016/j.compind.2014.12.012

[17] Ahmad, M. M. \& Pinedo-Cuenca, R. (2013). Critical success factors for ERP implementation in SMEs. Robotics and Computer-Integrated Manufacturing, 29(3), 104-111. https://doi.org/10.1016/j.rcim.2012.04.019

[18] Ram, J., Corkindale, D., \& Wu, M. L. (2013). Implementation critical success factors (CSFs) for ERP: Do they contribute to implementation success and postimplementation performance? International Journal of Production Economics, 144(1), 157-174. https://doi.org/10.1016/j.jpe.2013.01.032

[19] Ehie, I. C. \& Madsen, M. (2005). Identifying critical issues in enterprise resource planning (ERP) implementation. Computers in Industry, 56(6), 545-557. https://doi.org/10.1016/j.compind.2005.02.006

[20] Buonanno, G., Faverio, P., Pigni, F., Ravarini, A., Sciuto, D., \& Tagliavini, M. (2005). Factors affecting ERP system adoption: A comparative analysis between SMEs and large companies. Journal of Enterprise Information Management, 18(4), 384-426. https://doi.org/10.1108/17410390510609572

[21] Motwani, J., Subramanian, R., \& Gopalakrishna, P. (2005). Critical factors for successful ERP implementation: Exploratory findings from four case studies. Computers in Industry, 56(6), 529-544. https://doi.org/10.1016/j.compind.2005.02.005

[22] Ngai, E. W. T., Law, C. C. H., \& Wat, F. K. T. (2008). Examining the critical success factors in the adoption of enterprise resource planning. Computers in Industry, 59(6), 548-564. https://doi.org/10.1016/j.compind.2007.12.001 
[23] Šimunović, K., Šimunović, G., Havrlišan, S., Pezer, D., \& Svalina, I. (2013). The Role of ERP System in Business Process and Education. Technical Gazette. 20(4), 711-719.

[24] Nikitovic, M. \& Strahonja, V. (2016). The analysis of CSFs in stages of ERP implementation? Case study in small and medium-sized (SME) companies in Croatia. In: $39^{\text {th }}$ International Convention on Information and Communication Technology, Electronics and Microelectronics, 1494-1499. Croatian Society MIPRO. https://doi.org/10.1109/MIPRO.2016.7522375

[25] Leyh, C. (2014), Critical Success Factors for ERP Projects in Small and Medium-sized Enterprises-The Perspective of Selected German SMEs. Proceedings of the 2014 Federated Conference on Computer Science and Information Systems, 1181-1190, September 6-10, Warsaw, Poland. https://doi.org/10.15439/2014F243

[26] Katerattanakul, P., Hong, S., \& Lee, J. (2006). Enterprise resource planning survey of Korean manufacturing firms. Management Research News, 29(12), 820-837. https://doi.org/10.1108/01409170610717835

[27] Rosemann, M., Klaus, H., \& Gable, G. G. (2000).What is ERP? Information System Frontiers, 2(2), 141-162. https://doi.org/10.1023/A:1026543906354

[28] Eskillson, H., Nystron, C., \& Windler, M. (2003). ERP Systems Effects - A Comparison of Theory and Practice. School of Economics and Commercial Law, Goteborg University.

[29] Olhager, J. \& Seldin, E. (2003). Enterprise Resource Planning Survey of Swedish Manufacturing Firms. European Journal of Operational Research, 146(2), 365373. https://doi.org/10.1016/S0377-2217(02)00555-6

[30] Shehab, E. M., Sharp, M. W., Supramaniam, L., \& Spedding, T. A. (2004). Enterprise resource planning: An integrative review". Business Process Management Journal, 10(4), 359386. https://doi.org/10.1108/14637150410548056

[31] Grabski, S. V. \& Leech, S. A. (2007). Complementary controls and ERP implementation success. International Journal of Accounting Information Systems, 8(1), 17-39. https://doi.org/10.1016/j.accinf.2006.12.002

[32] Al-Mashari, M. (2002). Enterprise resource planning (ERP) systems: a research agenda. Industrial Management \& Data Systems, 102(3), 165-170. https://doi.org/10.1108/02635570210421354

[33] Berchet, C. \& Habchi, G. (2005). The implementation and deployment of an ERP system: An industrial case study. Computers in Industry, 56(6), 588-605. https://doi.org/10.1016/j.compind.2005.02.009

[34] Mabert, V. A., Soni, A., \& Venkataramanan, M. A. (2003). The impact of organization size on enterprise resource planning (ERP) implementations in the US manufacturing sector. Omega, 31(3), 235-246. https://doi.org/10.1016/S0305-0483(03)00022-7

[35] Koh, S. C. L., Gunasekaran, A., \& Cooper, J. R. (2009). The demand for training and consultancy investment in SMEspecific ERP systems implementation and operation. International Journal of Production Economics, 122(1), 241-254. https://doi.org/10.1016/j.ijpe.2009.05.017

[36] Yen, H. J. R. \& Sheu, C. (2004). Aligning ERP implementation with competitive priorities of manufacturing firms: An exploratory study. International Journal of Production Economics, 92(3), 207-220. https://doi.org/10.1016/j.jpe.2003.08.014

[37] Yusuf, Y., Gunasekaran, A., \& Abthorpe, M. S. (2004). Enterprise information systems project implementation: A case study of ERP in Rolls-Royce. International Journal of Production Economics, 87(3), 251-266. https://doi.org/10.1016/j.jpe.2003.10.004

[38] Ehsan Kish, H. S., Jusoh, A., Mardani, A., \& Bagheri, M. M. (2015). Successful Enterprise Resource Planning Post-
Implementation: Contributions of Technological Factors. Journal of Soft Computing and Decision Support Systems, 2(4), 17-25.

[39] Snider, B., da Silveira, G. J. C., \& Balakrishnan, J. (2009). ERP implementation at SMEs: analysis of five Canadian cases. International Journal of Operations \& Production Management, 29(1), 4-29. https://doi.org/10.1108/01443570910925343

[40] Sheu, C., Chae, B., \& Yang, C.-L. (2004). National differences and ERP implementation: issues and challenges. Omega, 32(5), 361-371. https://doi.org/10.1016/j.omega.2004.02.001

[41] Worley, J. H., Chatha, K. A., Weston, R. H., Aguirre, O., \& Grabot, B. (2005). Implementation and optimisation of ERP systems: A better integration of processes, roles, knowledge and user competencies. Computers in Industry, 56(6), 620638. https://doi.org/10.1016/j.compind.2005.03.006

[42] Wang, E. T. G., Lin, C. C. L., Jiang, J. J., \& Klein, G. (2007). Improving enterprise resource planning (ERP) fit to organizational process through knowledge transfer. International Journal of Information Management, 27, 200212. https://doi.org/10.1016/j.jijnfomgt.2007.02.002

[43] Pacheco-Comer, A. A. \& González-Castolo, J. C. (2012). An empirical study in selecting Enterprise Resource Planning Systems: The relation between some of the variables involve on it. Size and Investment. Procedia Technology, 3, 292-303. https://doi.org/10.1016/j.protcy.2012.03.032

[44] Sun, A. Y. T., Yazdani, A., \& Overend, J. D. (2005). Achievement assessment for enterprise resource planning (ERP) system implementations based on critical success factors (CSFs). Int. J. Production Economics, 98, 189-203. https://doi.org/10.1016/j.ijpe.2004.05.013

[45] Christmann, A. \& Van Aelst, S. (2006). Robust estimation of Cronbach's alpha. Journal of Multivariate Analysis, 97, 1660-1674. https://doi.org/10.1016/j.jmva.2005.05.012

\section{Contact information:}

Krunoslav HORNUNG, PhD student

Srednja Škola Valpovo,

Dr. Franje Tuđmana 2 ,

31551 Valpovo, Croatia

E-mail: khornung@sfsb.hr

Maja HORNUNG, master of informatics

Croatia Osiguranje

Jagićeva ulica 33

10000 Zagreb, Croatia

E-mail: maja.hornung@gmail.com 